\title{
ORGANIZATIONAL PARTNERSHIPS IN BRAZIL: PROBLEMS AND CHALLENGES IN SOLID WASTE
}

PARCERIAS ORGANIZACIONAIS NO BRASIL: PROBLEMAS E DESAFIOS EM RESÍDUOS SÓLIDOS

\author{
Recebido em 12.11.2018. Aprovado em 20.02.2019 \\ Avaliado pelo sistema double blind review \\ DOI: http://dx.doi.org/10.12712/rpca.v13i1.27267
}

\section{Cintia Rodrigues de Oliveira Medeiros}

cintia@ufu.br

Programa de Pós-graduação em Administração da Universidade Federal de Uberlândia (UFU) - MG, Brasil

ORCID: https://orcid.org/0000-0001-7999-9002

\author{
Valdir Machado Valadão Júnior \\ valdirjr@ufu.br \\ Programa de Pós-graduação em Administração da Universidade Federal de Uberlândia (UFU) - MG, Brasil \\ ORCID: https://orcid.org/0000-0001-7930-8056
}

\section{Leonardo Rodrigues Pires}

leorpires@yahoo.com.br

Programa de Pós-graduação em Administração da Universidade Federal de Uberlândia (UFU) - MG, Brasil

ORCID: https://orcid.org/0000-0001-9727-6764

\section{Mayla Cristina Costa}

mayla.c.costa@gmail.com

Programa de Mestrado e Doutorado em Contabilidade da Universidade Federal do Paraná (UFPR) - PR, Brasil

ORCID: https://orcid.org/0000-0002-2909-3103

\begin{abstract}
This paper aims to provide an understanding of how solid waste proposals align between organizations that collect recyclable materials and other responsible groups; to explain how these partnerships of selective collection work in the city of Uberlândia/MG in Brazil; to document the achievement of these solid waste activities; and to present the problems and challenges of social governance in solid waste from the perspective of each player. We used methods of document analysis, interviewing, and, most importantly, the shadowing technique in our research. At the end of 2016, it was found that Municipal Law 12,504 has proven to be a challenge for both the players and the government because more is being asked of this organized social movement to promote better alignment between everyone involved.
\end{abstract}

Keywords: Intersectoral Partnerships. Selective Collection. Social Governance. Solid Waste.

\section{Resumo}

O objetivo deste artigo é compreender o alinhamento entre as propostas das organizações de catadores de materiais recicláveis e dos demais membros responsáveis pela institucionalização da parceria da coleta seletiva de Uberlândia / MG no Brasil, documentar a resolução da atividade, para apresentar os problemas e desafios da governança social em resíduos sólidos, a partir da perspectiva de cada ator social envolvido. Usamos métodos de análise de documentos, entrevistas e, especialmente, a técnica de sombreamento. Identificou-se que a entrada em vigor, no final de 2016, da Lei Municipal 12.504, mostrou-se um desafio aos atores e ao governo, pois, cada vez mais, pede-se ao movimento social organizado que melhore o alinhamento entre todos os atores envolvidos.

Palavras-chave: Parceria Intersetorial. Coleta Seletiva. Governança Social. Resíduos Sólidos. 


\section{Introduction}

Over the past two decades, research has increased on the topic of social movements and the growing need for local partnerships to solve complex problems. The theory, process, and ethics of social governance has emerged to deal with various social problems, from public health (Veenstra, 2002; Kickbusch \& Gleicher, 2012) and solid waste (Bhuiyan, 2010; Hoornweg \& Bhada-Tata, 2012) to the quest for democracy without social exclusion. Citizens in all societies face these problems as politicians and policymakers face questions of "perverse" transverse governance (Ocampo, 2018). A common finding among researchers relates to the essential element as the need of a "partnership" between the public and private sectors, voluntary and community organizations, and other interests' actors in solving any of these complex problems.

One theme of great interest among public management professionals and communities is the growth of urban solid waste production and, consequently, the impacts and costs generated in their treatment and disposal (Dias, 2009; IPEA, 2013). The explanation for the occurrence of this phenomenon is directly related to several factors, such as population increase, accelerated urbanization process, technological changes, and improvement in the socioeconomic conditions of the society. In this context, the world's urban population is responsible for the consumption of 70 percent of global natural resources and for approximately 80 percent of global carbon emissions (Besen, 2011).

Issues associated with the adequate treatment of solid urban waste and to recycling appear prominently in the environmental discussion agenda, in terms of minimizing impacts generated by human activities, (Gonçalves Dias, 2009; IPEA, 2013). The selective collection of household solid waste and the recycling of the resulting materials are one method to reduce: 1) the impact on ecosystems and biodiversity; 2) the consumption of natural resources and inputs, such as water and energy; and 3) the disposal and burning of waste. Other benefits associated with selective collection and recycling include reducing the consumption of inputs in the production process; reducing greenhouse gas emissions, generation of employment, and income; and improving of the quality of urban cleaning (Besen, 2011).

Despite the benefits mentioned, most Brazilian municipalities do not carry out the selective collection of municipal solid waste. Of the 5.570 existing municipalities, only 1,322 are reported to have this service, according to the National Sanitation Information System (SNIS, 2016) survey. In addition, according to this research, from a total amount of 64 million tons of urban solid waste collected in 2014, less than 2 percent (1.3 million) of this amount was recovered through selective collection. Considering that, on average, 30 percent of domestic and public waste can be recycled, selective collection programs in Brazil are still inefficient in the recovery of these materials. Another characteristic of the selective collection system in Brazil is the relevant participation of the collectors of recyclable materials. In 2014, the activities of these agents-organized in cooperatives and associations and in partnership with the local public power-were responsible for the recovery of 43.5 percent of the total waste collected selectively in the country (SNIS, 2016). However, the participation of recyclable waste collectors in relation to the quantity of materials recovered and sent to recycling is even greater, since about two-thirds of these collectors work autonomously (IPEA, 2013).

According to Dias (2009), the birth and expansion of the recycling industry were favored, especially, due to the insertion of thousands of workers in the activities of collecting recyclable materials. Waste collectors usually carry out the collection, separation, transportation, packaging, and sometimes solid waste processing that are useful for the reuse and recycling market (IPEA, 2013). Even though they constitute a heterogeneous group, these workers, in general, perform this activity as a means of survival and are exposed to precarious conditions and social exclusion (Loschiavo-dos-Santos, 2008; Dias, 2009; Besen, 2011; IPEA, 2013 
Thus, to better understand how these partnerships occur and what the objectives of each of the partners, this article aims to identify social governance in the area of solid waste treatment, through the partnerships formed in the process, in the city of Uberlândia, Minas Gerais. Partnerships between the public and private sectors and civil society have taken place in Brazil for a long time. Fischer (2002) finds that partnerships between the private sector and civil society reflect the steady decline of state participation in the provision of public services. In relation to partnerships between civil society and public authorities at the local level, Farah (2001) argues that we are living in a time of rebuilding state relations with society toward a democratization of management and public policies because of this movement. Thus, studies involving intersectoral partnerships are relevant, given that it is a new reality and it is still necessary to better understand how these partnerships occur in practice.

Another practical justification for this work lies in the importance of the recycling process as a way of making human activity less harmful to the environment. Since urban solid waste, derived from household consumption and commerce, makes up a considerable part of the recyclable materials, and is not yet recycled, the importance of research that helps to clarify the factors that make it difficult to achieve this is noticeable goal. In this sense, research is justified to also understand if there is a possible misalignment among the participants of the collection partnership.

The research results are organized in the following four sections. Section Two presents the theoretical reference, focusing on the theoretical lens that serves as the basis for the discussion of empirical analysis. Section Three reviews the methodological procedures, the data, and results obtained. Finally, Section Four offer the final considerations.

\section{Partnerships in selective collection: origin and members}

Partnerships in selective collection programs have the potential to reduce their costs, to enable the effective participation of various sectors of civil society, and to improve them in general (Grimberg; Blauth, 1998). These partnerships are the cornerstone of change from the perspective of dealing with issues related to solid waste management, moving from a predominantly technical view to an integrated and shared management vision. Technological, economic, cultural, and social variables become central to the formulation and implementation of solid waste management strategies (Demajorovic; Besen; Rathsam, 2006).

Integrated management of solid urban waste (GIRSU) emerged in Brazil in the 1980s, in the context of a transformed role for the state, which focused mainly on its relationship with civil society. In fact, the development and multiplication of practices of reinforcement of the autonomy and legitimacy of social actors, by civil society, have generated the valorization of partnerships and proposals for action and intervention based on cooperation, solidarity and participation (Besen, 2011). In political terms, according to Demajorovic, Besen and Rathsam (2006), the return of direct municipal elections favored the adoption of new democratic channels in the decision-making process. This made it possible for municipal management proposals based on social mobilization and the incorporation of socioenvironmental themes to influence this process. In this sense, the realization of Rio 92 and the publication of Agenda 21 have contributed greatly to increasing visibility on environmental issues in the Brazilian context (Demajorovic; Besen; Rathsam, 2006).

Concerns about reducing waste generation, increased recycling through selective collection programs to reduce landfill use, and environmental education initiatives began to have an influence on social movements, such as public sector actions. In the social aspect, the recognition of scavengers as a central member of GIRSU was also fundamental to the process of adopting partnerships (Demajorovic; Besen; Rathsam, 2006). 
In studies of solid waste management partnerships in developing countries, Grafakos, Baud, and Klundert (2001) identified several social actors, who, due to their characteristics and roles, were grouped into the following groups:

Figure 1 - Possible partnerships in the management of urban solid waste

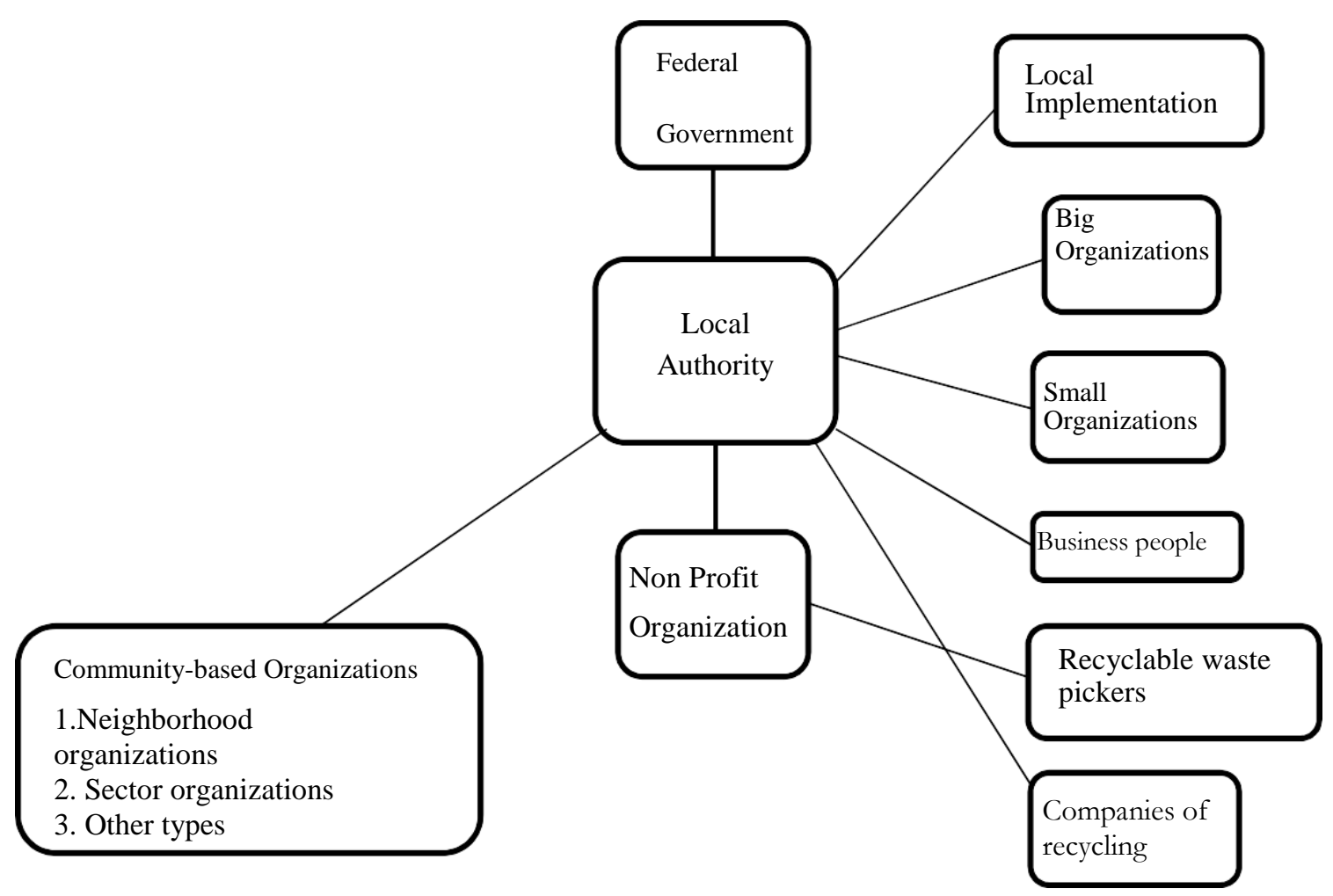

Source: Adapted from Grafakos, Baud and Klundert (2001, p. 14)

To analyze the effectiveness of alliances between two or more social actors, Grafakos, Baud and Klundert (2001) point out that the conditions under which partnerships are established must be considered. Therefore, the following points should be analyzed: 1) the structures of the political/regulatory environment and their relationship with the prevailing conditions in the provision of solid waste management services; 2) the existing organizational map that seeks to identify how the actors are linked to each other, who is included and who is excluded, the classes of contracts and conditions established, and the limits created by the organizational context; and 3) the technical means available to the actors to develop their activities. The policy/regulatory framework defines how activities will be carried out, although this framework is subject to long-term change. The conduction of activities is derived from the combination of the organizational context and the technical means used in solid waste management activities. Changes in this system can occur in each of these three factors, which can influence other areas and affect the performance of the services.

Grafakos, Baud and Klundert (2001) recommend a systematic analysis of these three dimensions in relation to the objectives of the alliance and contributions. In this sense, the analysis of these three dimensions contributes to the evaluation of operational aspects and management of partnerships in the execution of social projects, as proposed by Bronzo, Teodósio and Rocha (2012) and mentioned in the section of this work on partnerships with organizations of the third sector. In this way, it is possible to verify the existence of problems that may arise in partnerships, mainly those related to the instability of monitoring and evaluating the projects' social interventions, in this case, the selective collection program of the municipality of Uberlândia, Minas Gerais, in Brazil. 


\section{Research Design}

This case study is constructed as contemporary analysis of the study object in the context in which it is inserted (Yin, 2001; Gil, 2008), and is useful for our understanding of individual, organizational, social, political and cultural phenomena (Yin, 2001, 21). In the present study, the unit of analysis is the interorganizational partnership constituted to execute the public service of selective solid waste collection produced in the city of Uberlândia. Thus, we analyzed the partnership between City Hall, one private organization (Limpebras), and six garbage collectors' organizations.

We used the shadowing method of data collection. In comparison to other methods, Quinlan (2008) points out that this technique is based more on current events than on past events, using information obtained through focus groups and interviews. In addition, the information collected through shadowing is more detailed than that obtained through other commonly used approaches. For example, the data collected is not an interpretation of the individual's role in the organization, but, rather, is collected through direct observation or shadowing. By observing participants using this research method, the researcher collects focused and specific perspectives of an experience, which is particularly relevant to specialized functions. Therefore, the data obtained is more constructive because it is based on the specialist's opinions and rather than that of a novice (in this case, the researcher) (McDonald, 2005).

On average, our research included about 10 hours of follow-up with each organization, and the team responsible for collecting the materials spent almost five hours of follow-up with each organization. This amount of time was not adequate to fully comprehend all objectives of the research, and we understand that more time should have been dedicated to this aspect; however, our intention for the monitoring was, mainly, to clearly understand all aspects of the activity.

Another point related to the shadowing technique is the fact that those who have previous experience with the organizations of scavengers and employees of SMSU will have more success in negotiating access to the organizations and the workers chosen to be accompanied. Generally, this is presented as one difficulty in employing the technique, since permission to shadow sanitation workers may be difficult to achieve based on the longer and less conventional involvement, when compared to techniques such as the interview (McDonald, 2005).

The main difficulty with the use of the technique was experienced in the organizations of collectors, because it was challenging, to dissociate us from the role of volunteers and to become researchers. Because of this, we were asked a few times to position ourselves in relation to some facts and to assist them in some activities that we had performed previously as a volunteer.

However, the greatest challenge in employing shadowing is the treatment of the information obtained. The daily recording of information and its processing at the end of the day, to preserve its quality and contemporaneousness, is a challenge for any researcher (McDonald, 2005). To deal with this difficulty, we used a small notebook to make quick notes about what they observed and our conversations during our follow-up with individuals. At the end of the day, based on these notes, we made audio recordings of our accounts, detailing the experiences of the shadowing experience. Subsequently, we transcribed all these audios to compose the field diary, which formed the body of this research.

Finally, we are aware of the possibility that the occurrence of the Hawthorne influence (which states that people's behavior and performance can change when they are being observed) could alter the validity of this research. However, we believe that this effect did not occur in a way to compromise this research. As Quinlan (2008) states, it is more likely to occur when the shadowed subject knows and relates to the researcher over time during the shadowing. However, this effect may not occur when the researcher spends a shorter period with the shadowed subject (Quinlan, 2008). 
Qualitative analyses of data, unlike quantitative analyses, are highly dependent on the researcher's acumen and style, because there is no well-defined road map of how to do them (Yin, 2001; Gil, 2008). In general, qualitative analyses are characterized by two phases: 1) organization of all collected material and division into parts, to identify relevant trends and patterns; and 2) reassessment of these trends and patterns with the aim of establishing new relationships and inferences of the highest level of abstraction (Ludke and André, 1986).

The data analysis procedure usually begins at the collection stage, occurring concomitantly with it. However, more effectively, an analysis begins after the closure of this collection phase (Ludke and André, 1986; Gil, 2008). In this work, the body of the research consists of the following items:

1) field diary (40 pages);

2) interview transcript (9 pages);

3) documents related to the partnerships (82 pages);

4) website of the component organizations of the partnership (45 pages);

5) documents related to the functioning of these organizations ( 77 pages); and

6) municipal legislation on solid waste management (296 pages).

All this material total 506 pages of analysis. We added the previous experience of one researcher with collectors' organizations and the discussion follow-up between these entities and others involved in the partnership. These multiple sources of data were analyzed from the perspective of triangulation to give greater reliability to the analysis and to avoid its commitment due to reflexivity (Bauer and Gaskell, 2002).

The process of data analysis was based on the technique of content analysis proposed by Bardin (1977). This analysis is divided chronologically into three phases: 1) pre-analysis; 2) exploitation of the material; and 3) treatment of results, inference, and interpretation. In pre-analysis, the main objective is to organize the material to be analyzed in a systematized way. The body of research was organized according to its origin, that is, according to who produced it. Thus, it was divided into the material produced by City Hall (PMU), by Limpebras (private organization), and by the collectors' organizations.

\section{Findings}

\section{Case - Selective Collection Program of Uberlândia/MG}

The Selective Collection Program in the Municipality of Uberlândia began in January 2011, through a pilot project carried out in the Santa Mônica and Segismundo Pereira Districts. The main model used to collect waste is the door-to-door method, which employs a truck with a driver and two collectors with a schedule of days and times that is different from the conventional collection to collect the waste previously separated by the neighborhoods' residents (PMU, 2012c).

Before the service is deployed in a specific sector of the city, residents are made aware of the correct way to separate waste, the truck route's pick-up schedule of days and times, and the correct way to package waste for pick-up, because residents are oriented to separating the garbage in dry and humid residues. Specifically, the dry waste should be placed in common trash bags on the sidewalk of the residences only on the day of the selective collection, while humid residues should be arranged on the days of conventional collection. This awareness process is carried out by members of the collectors' organizations as approved by City Hall and trainees contracted by the company that provide the public cleaning service of the city, Limpebras (PMU, 2015).

To carry out the selective collection service, 10 trucks are currently employed. These trucks are owned by the drivers themselves, who are members of a transportation cooperative subcontracted by Limpebras. All trucks have trackers and, according to the PMU (2015), are monitored by City Hall staff to check for 
possible deficiencies in the route. The 20 collectors working on pickup trucks (two per truck) are employees of Limpebras.

In addition to the door-to-door collection, Voluntary Delivery Points (PEVs) are available where resident can drop off recyclable waste produced in their homes. These PEVs are composed of 12 Ecopointscreated mainly to receive small quantities of solid construction waste-and six organizations of recyclable waste collectors that participate in partnership with the municipality. PEVs were also created in two rural regions of the city of Uberlândia, in the localities of Tenda dos Morenos and Ólhos D'água (PMU, 2015).

Regarding the scope of the selective collection program, by the end of 2011, it already served about a quarter of the urban population of the municipality and, within a period of three years, it was expected that the service would serve the entire population (PMU, 2012c). However, this service currently serves 28 city districts, which corresponds to 44.6 percent of the total population of the municipality. Table 1 shows the amounts collected through the program and the conventional garbage collection from the years 2011 through 2016.

Table 1 - Performance of the Selective Collection Program of Uberlândia/MG

\begin{tabular}{|c|c|c|c|c|c|c|}
\hline & \multicolumn{6}{|c|}{ Year } \\
\hline & 2011 & 2012 & 2013 & 2014 & 2015 & 2016 \\
\hline $\begin{array}{l}\text { Selective collections } \\
\text { (tons) }\end{array}$ & $1.243,60$ & $1.797,30$ & $1.631,20$ & $2.020,00$ & $2.231,70$ & $2.003,75$ \\
\hline $\begin{array}{l}\text { Garbage Collection } \\
\text { (Domicile and Public) } \\
\text { (tons) }\end{array}$ & $156.216,50$ & $164.373,00$ & $168.331,40$ & $174.848,30$ & $178.664,70$ & Without info \\
\hline Total & $157.460,10$ & $166.170,30$ & $169.962,60$ & $176.868,30$ & $180.896,40$ & Without info \\
\hline $\begin{array}{l}\text { Participation of the } \\
\text { selective collection on } \\
\text { Total Collected }\end{array}$ & $0,79 \%$ & $1,08 \%$ & $0,96 \%$ & $1,14 \%$ & $1,23 \%$ & Without info \\
\hline $\begin{array}{l}\text { Population served by } \\
\text { selective collection } \\
\text { (hab) }\end{array}$ & 149.600 & 210.823 & 250.929 & 266.390 & 269.000 & 257.264 \\
\hline $\begin{array}{l}\text { Collected Qty Collect } \\
\text { Selective hab / year }\end{array}$ & 8,31 & 8,53 & 6,50 & 7,58 & 8,30 & 7,79 \\
\hline
\end{tabular}

The data indicates stagnation in the program related to the service's expansion to the population, since, in much the last four years, there was no increase in the number of inhabitants served by the service. Also noteworthy is the low amount of waste collected through selective collection in relation to total household solid waste, as well as that in public places collected by conventional collection. Approximately only 1 percent of these wastes were collected as a function of the program being studied. It is worth noting that this percentage is only slightly higher than that of the city of Maputo, the capital of Mozambique in Africa, according to the work of Buque and Ribeiro (2015). The authors point out limitations that have not been overcome, to a certain extent, in Brazil's selective collection program, such as the absence of an industrial park to consume the raw materials for recycling and the absence of a municipal legal framework for selective collection.

From the above program data, and other research, we can verify that the partnership to carry out the selective collection in the city of Uberlândia is structured as follows: The city is responsible for contracting with Limpebras, the company in charge of collecting recyclable material through the doorto-door method. City Hall is also the manager of the agreement established between it and the 
organizations of collectors in which the collected material is sent for selection and marketing with intermediaries and recycling industries. The management of the program is carried out by the Selective Collection Management Committee, which includes members of City Hall, collectors' organizations, and the Federal University of Uberlândia. Thus, according to IBAM (2001) and Grafakos, Baud, and Klundert (2001), the participation of City Hall is central, being responsible for the mediation between other members of the system and for the provision of infrastructure and costing of the program. Together with other members, especially with the collector organizations, City Hall develops, through the Selective Collection Management Committee, the activities of developing regulations, planning, awareness programs (IBAM, 2001; Baptista, 2015).

\section{Partnerships and each player's perspective: problems and challenges}

The analysis of the positioning alignment configuration, together with the comparison of the objectives, allowed us to identify a tendency toward a confrontational and cooptation relationship between the collectors' organizations and the other partners, according to the Najam (2000) classification. Because their objective is difficult to reconcile with those of City Mall and Limpebras managers, these are the probable ways of establishing the relationship between these agents. Regarding the urgency of developing the selective collection program, organizations have in their favor the position established in the laws, and it is up to them to fight for the effectiveness of the policies that the legislation seeks to induce.

The program's stagnation in relation to the increase in the population served and the decrease in the quantity of recyclable material collected indicate that the existence of legislation favorable to the implementation of a public policy is not enough to ensure its effectiveness (Lima et al., 2011). Even the implementation of mechanized collection, (although it does not have the support of the law so that its impediment is promoted) can be questioned from the perspective that it is contrary to the legislation's objective to promote selective collection.

Regarding the concordant positioning among the scavengers' organizations, Limpebras and City Hall managers, because they are related to issues that are important for the development of the program, but were not in discussion at the moment of data collection, they do not favor the intensification of the cooptation relationship that would be established in the presence of concordant positions even though based on divergent objectives (Najam, 2000). Thus, considering the four aspects analyzed, we believe that the relationship, at the analyzed moment, can be characterized as confrontational.

However, the intensity of this confrontational dynamic will ultimately depend on the scavenger organizations' interest in developing the selective collection program. Based on the data collected from garbage collectors' organizations, we note that its members are apparently more concerned with other more lucrative and immediate activities for their members than with the selective collection program itself.

In Table 2 we can see the partners' positioning on the waste collection. We divided City Hall into two areas, where we analyzed the normative and the actors' practice separately. 
Table 2 Partners' Positioning on Selective Collection

\begin{tabular}{|c|c|c|c|c|}
\hline Features & $\begin{array}{l}\text { Garbage } \\
\text { Collectors } \\
\text { Organizations }\end{array}$ & $\begin{array}{l}\text { City Hall } \\
\text { (Normative) }\end{array}$ & $\begin{array}{c}\text { City Hall } \\
\text { (Actors Practices) }\end{array}$ & Limpebras \\
\hline $\begin{array}{c}\text { Absence of } \\
\text { incentive to } \\
\text { team of } \\
\text { collection of } \\
\text { recyclable materials }\end{array}$ & $\begin{array}{l}\text { Contrary. You can } \\
\text { reduce the } \\
\text { availability of } \\
\text { recyclable materials } \\
\text { for them. } \\
\text { (1) }\end{array}$ & $\begin{array}{l}\text { Contrary. Prejudices } \\
\text { of collectors, going } \\
\text { against the objective } \\
\text { of program. } \\
\text { (1) }\end{array}$ & $\begin{array}{l}\text { Contrary. Increases } \\
\text { the pressure for } \\
\text { changes in } \\
\text { program. } \\
\text { (1) }\end{array}$ & $\begin{array}{c}\text { Favorable. } \\
\text { More material for the } \\
\text { conventional } \\
\text { collection and } \\
\text { landfill. } \\
\text { (2) }\end{array}$ \\
\hline $\begin{array}{c}\text { Interest of } \\
\text { drivers in } \\
\text { continuing to lend } \\
\text { the services }\end{array}$ & $\begin{array}{c}\text { Favorable. } \\
\text { More material for } \\
\text { the } \\
\text { conventional } \\
\text { collection and } \\
\text { landfill. } \\
(1)\end{array}$ & $\begin{array}{l}\text { Favorable. Allows } \\
\text { achievement of } \\
\text { objectives of the } \\
\text { program. } \\
\text { (1) }\end{array}$ & $\begin{array}{c}\text { Favorable. Allows } \\
\text { that things stay } \\
\text { how they are. } \\
\text { (1) }\end{array}$ & $\begin{array}{l}\text { Favorable. Reduces } \\
\text { pressure to promote } \\
\text { improvement in the } \\
\text { conditions } \\
\text { of hiring. } \\
\text { (1) }\end{array}$ \\
\hline $\begin{array}{l}\text { Institution of the } \\
\text { payment per ton } \\
\text { per service team } \\
\text { collection }\end{array}$ & $\begin{array}{l}\text { Favorable. High } \\
\text { probability of } \\
\text { increasing the } \\
\text { availability of } \\
\text { of recyclable } \\
\text { materials. } \\
\text { (1) }\end{array}$ & $\begin{array}{l}\text { Favorable. Favors } \\
\text { the garbage collectors' } \\
\text { and } \\
\text { reduces the amount } \\
\text { of material sent to the } \\
\text { landfill. } \\
\text { (1) }\end{array}$ & $\begin{array}{l}\text { Positioning not } \\
\text { identified. } \\
(0)\end{array}$ & $\begin{array}{c}\text { Contrary. Has } \\
\text { discharge } \\
\text { probability of reducing } \\
\text { billing } \\
\text { company. } \\
\text { (2) }\end{array}$ \\
\hline $\begin{array}{l}\text { Non-execution of } \\
\text { services by } \\
\text { Limpebras }\end{array}$ & $\begin{array}{l}\text { Favorable. } \\
\text { Opportunity to } \\
\text { increase } \\
\text { the income of } \\
\text { members in } \\
\text { function } \\
\text { remuneration for } \\
\text { the service } \\
\text { provided. } \\
(1)\end{array}$ & $\begin{array}{c}\text { Favorable. Proposal } \\
\text { brought by law } \\
\text { Municipal 12.504/ } \\
\text { 2016, which is aligned } \\
\text { with } \\
\text { the regulations } \\
\text { above. } \\
\text { (1) }\end{array}$ & $\begin{array}{l}\text { Positioning not } \\
\text { identified. } \\
(0)\end{array}$ & $\begin{array}{c}\text { Contrary. Decrease } \\
\text { of non-billing } \\
\text { provides services and } \\
\text { the } \\
\text { reduction possibility } \\
\text { case of material } \\
\text { recyclable } \\
\text { conventional. } \\
\text { (2) }\end{array}$ \\
\hline
\end{tabular}

\section{Source: Authors}

Caption: Number (1) blocks indicate that the positioning favors the selective collection program. Number (2) blocks indicate that the positioning impairs the program. When different agent placements have equal colors, a consensus exists between them; when they have different colors, there is dissent.

This analysis allowed us to identify the areas of consensus and dissent among the partnership membership created to carry out the municipal selective collection in Uberlândia. We found that, at the time of data collection, the points identified as relevant to the program's performance included two pairs of consensuses, which present the entities that formed each significant pair of alignments between their positions. However, the positioning between the pairs is predominantly marked by dissent.

In this context, it is important to note that, in this case, the use of recyclable waste pickers is not an option. And, on the other hand, there are the managers of City Hall and Limpebras. This disagreement between peers was triggered mainly by the first pair's interest in implementing program changes, and by the second pair's interest in having the program remain unchanged.

Obviously, consensus among all members could occur if one pair changed its mind. On the one hand, this could occur if waste pickers' organizations and municipal legislation on the subject fail to prioritize the implementation of program changes. On the other hand, if could also occur if Limpebras and City Hall prioritized the implementation of these changes.

Due to the existence of a favorable political and ideological conjuncture-such as the return of direct municipal elections, the publication of Agenda 21, and the realization of Rio 92 (Demajorovic; Besen; Rathsam, 2006) - the implementation of selective collection programs that, effectively, fulfill their role of returning recyclable urban solid waste to the productive cycle (a situation that has already materialized 
in law at federative level). We believe it is more likely that, for a greater consensus among the members, it would be necessary that the Cleaners and the managers of the city hall start to prioritize the implementation of changes in the program.

As for Limpebras, if its main objective for participating in the partnership is to increase revenue and profits, a consensus could be achieved among its members if financial mechanisms were created that encourage an increase in the material collected in the selective collection program. However, to create consensus among members, especially between the collectors' organizations and the others, we believe it would also be necessary to create mechanisms that promote financial incentives so that members see how the processing of recyclable materials of the selective collection could increase their income. Otherwise, they would be at risk of increasing the material collected, but not the amount processed by the scavenger organizations.

Both mechanisms of financial incentive would cause an increase in City Hall's program expenses. Given the financial conditions, which are apparently unfavorable to the increase in expenses (during the time we collected survey data, City Hall was having difficulty paying for the services performed by Limpebras, which drivers of the material collection teams of the program), we believe that such a solution would be impracticable at present. Perhaps, this is one of the reasons that City Hall proposed the creation of Municipal Law 12,504/2016, which provides for the exclusivity of waste picker organizations to provide all services related to the program (PMU, 2016). According to Grimberg and Blauth (1998), the involvement of scavenger organizations in the execution of these programs has the potential to reduce their costs.

However, with the exclusion of Limpebras from the performance of these services, the possibility of creating consensus between it and the other members is practically infeasible because its revenues will be reduced, which is contrary to its objective. But with its exclusion from the partnership of the selective collection program, we believe it does not make sense to analyze consensus with members who do not belong to the solid waste program. We emphasize that although the possibility exists for Limpebras to continue to provide other urban cleaning services, it does not belong to the selective collection partnership or integrate into the study objectives, since its focus is exclusively on said program.

Under these conditions, Limpebras is remains a member of the partnership in the municipality (as well as the garbage collectors' organizations and City Hall), which can also be assumed and studied as a partnership, but from a much broader perspective than the partnership established to carry out a program of selective collection. In fact, according to IBAM (2001), a selective collection program is only one of the Public System Management constituent parts, which reinforce the unit of analysis for this research as the partnership of the selective collection program and not the Public System Management.

Therefore, based on the above considerations, and assuming the nonparticipation of Limpebras in the selective collection program as a result of the application of Law 12,504/2016, in Table 3 we present a matrix of possible consensuses and dissents of this new partnership proposed by law. Since Limpebras was excluded, aspects related to its operation will not be analyzed, and the analysis of the aspect referring to the final disposal of solid urban waste was it also dealt with an aspect more related to the performance of this company, or better, of its affiliate, to solid waste. 
Table 3 - Matrix of possible consensuses and dissents of the partnerships

\begin{tabular}{|c|c|c|c|c|c|}
\hline \multirow[t]{2}{*}{ Point of view } & \multicolumn{2}{|c|}{$\begin{array}{l}\text { Garbage Collectors } \\
\text { Organizations }\end{array}$} & \multirow{2}{*}{\begin{tabular}{|l} 
Normative \\
Legislation
\end{tabular}} & \multicolumn{2}{|c|}{ Managements } \\
\hline & $\begin{array}{l}\text { Actors who } \\
\text { agree } \\
\text { program is } \\
\text { aligned } \\
\text { with their } \\
\text { objectives }\end{array}$ & $\begin{array}{l}\text { Actors who } \\
\text { don't agree } \\
\text { program is } \\
\text { aligned with } \\
\text { their } \\
\text { objectives }\end{array}$ & & $\begin{array}{l}\text { Actors who } \\
\text { agree program } \\
\text { is aligned with } \\
\text { their objectives }\end{array}$ & $\begin{array}{l}\text { Actors who don't } \\
\text { agree program is } \\
\text { aligned with their } \\
\text { objectives }\end{array}$ \\
\hline $\begin{array}{c}\text { GIRSU - } \\
\text { Environment }\end{array}$ & $\begin{array}{c}\text { Recycling } \\
\text { (1) }\end{array}$ & $\begin{array}{c}\text { Recycling } \\
\text { (1) }\end{array}$ & $\begin{array}{l}\text { Reduction, } \\
\text { Reuse, Recycling } \\
\text { and Proper } \\
\text { Disposal. } \\
\qquad(1)\end{array}$ & $\begin{array}{l}\text { Reduction, Reuse, } \\
\text { Recycling, and } \\
\text { Proper Disposal. } \\
\text { (1) }\end{array}$ & $\begin{array}{c}\text { Indifferent } \\
(0)\end{array}$ \\
\hline $\begin{array}{l}\text { Conventional } \\
\text { Collection } \\
\text { Mechanized - } \\
\text { Solutions } \\
\text { Modern }\end{array}$ & $\begin{array}{l}\text { Against. } \\
\text { Deviates } \\
\text { recyclable } \\
\text { materials } \\
\text { from } \\
\text { selective } \\
\text { collection. } \\
(1) \\
\end{array}$ & $\begin{array}{l}\text { Indifferent } \\
(0)\end{array}$ & $\begin{array}{l}\text { Remiss in this } \\
\text { regard. } \\
(0)\end{array}$ & $\begin{array}{c}\text { Favorable. Search } \\
\text { for rationalizing } \\
\text { usage so as not to } \\
\text { compromise } \\
\text { selective collection. } \\
\text { (3) }\end{array}$ & $\begin{array}{l}\text { Favorable. It gives a } \\
\text { sense of modernity } \\
\text { to the municipality. } \\
\text { (2) }\end{array}$ \\
\hline $\begin{array}{l}\text { Sense of } \\
\text { urgency }\end{array}$ & $\begin{array}{l}\text { High } \\
(1)\end{array}$ & $\begin{array}{c}\text { Indifferent } \\
(0)\end{array}$ & $\begin{array}{l}\text { High } \\
\text { (1) }\end{array}$ & $\begin{array}{l}\text { High } \\
(1)\end{array}$ & $\begin{array}{l}\text { Low } \\
(2)\end{array}$ \\
\hline $\begin{array}{c}\text { Collection of } \\
\text { recyclable } \\
\text { materials by } \\
\text { scavenger } \\
\text { organizations in } \\
\text { public } \\
\text { organizations } \\
\text { and private } \\
\text { companies }\end{array}$ & $\begin{array}{c}\text { Not interested } \\
\text { if it disrupts } \\
\text { the activities } \\
\text { of the } \\
\text { selective } \\
\text { collection. } \\
\text { (1) }\end{array}$ & $\begin{array}{c}\text { Has interest, even } \\
\text { undermining } \\
\text { Selective } \\
\text { Collection. } \\
\text { (2) }\end{array}$ & $\begin{array}{l}\text { It allows and } \\
\text { obliges some } \\
\text { companies to } \\
\text { donate to } \\
\text { scavenger } \\
\text { organizations. } \\
\text { (1) }\end{array}$ & $\begin{array}{l}\text { Favorable. The } \\
\text { legislation allows. } \\
\text { (1) }\end{array}$ & $\begin{array}{l}\text { Favorable. It lowers } \\
\text { the pressure to } \\
\text { develop selective } \\
\text { collection. } \\
\text { (2) }\end{array}$ \\
\hline $\begin{array}{c}\text { Acquisition of } \\
\text { autonomous } \\
\text { waste picker } \\
\text { materials }\end{array}$ & $\begin{array}{l}\text { Not interested } \\
\text { if it disrupts } \\
\text { the activities } \\
\text { of the } \\
\text { selective } \\
\text { collection. } \\
\text { (1) }\end{array}$ & $\begin{array}{c}\text { Has interest. } \\
\text { Generates more } \\
\text { revenue and } \\
\text { supports external } \\
\text { scavengers. } \\
\text { (2) }\end{array}$ & $\begin{array}{l}\text { Remiss in this } \\
\text { regard. } \\
(0)\end{array}$ & $\begin{array}{c}\text { Favorable if it does } \\
\text { not disrupt the } \\
\text { selective collection. } \\
\text { (1) }\end{array}$ & $\begin{array}{l}\text { Favorable. It lowers } \\
\text { the pressure to } \\
\text { develop selective } \\
\text { collection. } \\
\text { (2) }\end{array}$ \\
\hline $\begin{array}{l}\text { Processing of } \\
\text { recyclable } \\
\text { materials by } \\
\text { waste pickers' } \\
\text { organizations }\end{array}$ & $\begin{array}{l}\text { Not interested } \\
\text { if it disrupts } \\
\text { the activities } \\
\text { of the } \\
\text { selective } \\
\text { collection. (1) }\end{array}$ & $\begin{array}{l}\text { Has interest. } \\
\text { Generates more } \\
\text { revenue. } \\
(2)\end{array}$ & $\begin{array}{l}\text { Remiss in this } \\
\text { regard. } \\
(0)\end{array}$ & $\begin{array}{c}\text { Favorable if it does } \\
\text { not disrupt the } \\
\text { selective collection. } \\
\text { (1) }\end{array}$ & $\begin{array}{l}\text { Favorable. It lowers } \\
\text { the pressure to } \\
\text { develop selective } \\
\text { collection. } \\
\text { (2) }\end{array}$ \\
\hline $\begin{array}{c}\text { Incapacity of } \\
\text { scavenger } \\
\text { organizations to } \\
\text { fulfill } \\
\text { obligations in } \\
\text { contractual } \\
\text { arrangements }\end{array}$ & $\begin{array}{l}\text { It disrupts } \\
\text { your goal. } \\
\text { Seek support } \\
\text { to fulfill. } \\
\text { (1) }\end{array}$ & $\begin{array}{l}\text { It disrupts your } \\
\text { goal, but you do } \\
\text { not strive to } \\
\text { comply. } \\
\text { (2) }\end{array}$ & $\begin{array}{c}\text { Disrupts } \\
\text { development of } \\
\text { the program. } \\
\text { (1) }\end{array}$ & $\begin{array}{l}\text { It hinders the } \\
\text { development of the } \\
\text { program. It is to } \\
\text { support the } \\
\text { scavenger } \\
\text { organizations to } \\
\text { comply. (1) }\end{array}$ & $\begin{array}{l}\text { It hinders the } \\
\text { development of the } \\
\text { program. It is to } \\
\text { support the scavenger } \\
\text { organizations to } \\
\text { comply. } \\
\text { (2) }\end{array}$ \\
\hline
\end{tabular}

Source: Authors

Caption: Number (1) blocks indicate that the placement favors the selective collection program. Number (2) blocks indicate that the positioning impairs the program. Number (3) blocks indicate that it is less detrimental to the program's purpose. When different agent placements have equal colors, a consensus exists between them. When they have different colors, there is dissent. 
We can observe the possibility of establishing consensus in practically all the analyzed points. To do so, it is necessary to convince SMSU managers of the importance of expanding and improving selective collection and to convince the scavengers organizations that remuneration from the program can contribute more income for its members than performing other activities.

In this situation, it is possible that the dynamics of collaborative relationships, as Najam (2000) points out, is predominantly marked by cooperation, since objectives and strategies of action would resemble each other. However, if scavenger organizations do not realize that the benefits of selective collection services are enough for them to prioritize the program, it is likely that conflicts will permeate the collaborative relationships, as proposed by Najam (2000).

The matrix analysis of consensuses and dissensions allows us to ascertain that, even with the exclusion of Limpebras from the partnership (which would, in theory, make possible greater alignment and consensuses between all the parties), challenges remain to build consensus between the partners and the partnership. As a result, as explained in the previous paragraph, the desired result can still be compromised.

This finding leads us to believe that the edition of Law 12,504 2016 will likely not be enough to guarantee that the selective collection program of the municipality of Uberlândia is developed within the federal law (BRASIL, 2010). This has implications for the aspects of involvement for collectors of recyclable materials, universalized attendance of the population, and the ability to prevent recyclable waste from reaching the landfill. The Law 12,504/2016 incorporates the space desired by garbage collectors, but it does not guarantee them an effective occupation in the recycling chain, since its position is still unfavorable and subordinate, and may be even more weakened depending on how the sector will be structured (Teodósio; Gonçalves-Dias; Santos, 2015).

\section{Final Remarks}

One of the authors of this paper has followed the selective collection program since its inception, in addition to having worked as a volunteer in its administrative activities. In the second half of 2016, he maintained contact with the organizations to carry out the data collection for this work. To do so, we sought to characterize each partner and identify their goals in relation to the program. Our method of collecting data was the analysis of documents (mainly, documents and organization websites, as well as normative regulations of their activities), interviewing and shadowing. This last method was chosen, above all, to include an analysis of each partner's observations of itself and the other members. Works with an interpretative approach are still unusual for the study of intersectoral partnerships in selective collection programs; therefore, this approach was used to better understand the perspective of each member of the partnership (Flick, 2009).

We were especially interested in the shadowing at Limpebras, given the lack of knowledge about its goals and how to approach the partnership. However, we did not have access to the person responsible for interfacing with the other members of the partnership. Therefore, we could only use data collected from their site and with others who had a relationship with the company. During our research, we found that one reason Limpebras employee refused to participate was the company's distance from the selective collection program and the misalignment between its objectives and those of the program.

In City Hall, we were surprised by the employees' receptivity and the absence of impediments to enter the organization. Frank information was provided, both by management and other employees, that greatly facilitated this phase of the research. This transparency allowed us to learn about the political influence on the program's decisions and the management of the organ in detail. We also learned about the distancing of City Hall managers from the routine of the operational area of the secretariat and their apparent disinterest in the program and the partnership. 
In turn, while gathering data from the collectors' organizations, we identified development plans based on the selective collection program, which we do not identify with the members. The plans were still unclear as to the directions the organization would like to take. What we found most noticeable in these organizations is that their struggle has remained the same for years: that is, the quest to become a source of work and income capable of providing a dignified life for its members. However, to meet this objective, they still had limited financial, technical, and structural resources.

As expected, we identified many conflicts of interest between the waste pickers' organizations and Limpebras, mainly caused by the company's financial incentive mechanisms, which made it preclude selective collection and prioritize conventional collection and the grounding of the waste solids. This is considered one of the main factors for the stagnation of selective collection in the period from 2013 to 2016. Another reason that contributed to this situation was the alignment between the implicit objective of Limpebras and the lack of interest among managers to make changes to the program. We questioned whether this alignment was casual or intentional while following this activity in Uberlândia, but there was not enough research information to resolve doubt on this specific aspect, which is a limitation of the study.

However, in relation to the comparison of the objectives of the waste collectors' organizations with the municipal legislation on solid waste management, we identified considerable alignment between them. We discovered that, since 2006, the laws on this subject have been published in favor of selective collection and the performance of the collectors. We were surprised, a few moments before the entrance on the field, with the news that the Municipal Law of Selective Solidarity Collection (PMU, 2016) had been approved. In principle, the organizations of collectors will have, from now on, real opportunities to achieve their objectives. After all, this is what federal and state legislators have been trying to implement for some time: the hiring of these entities to carry out selective collection service in municipalities. In fact, the voices of these entities represent and support the scavengers who have managed to be heard and then influence the creation of these legal procedures.

In general, our decision to use shadowing as the main means of data collection, which implies monitoring a specific person in each organization, the information means that the results collected may not represent the goals and proposals of the organizations they represent. As a result, this method prioritized the vision of a larger number of members of the organization, which could contribute to a greater understanding of how the phenomenon of partnerships is faced by those directly involved.

Many studies have been carried out to evaluate compliance with the National Solid Waste Policy, especially regarding the implementation of selective collection programs with the participation of waste pickers. Much of this work has identified difficulties related to the lack of financial and technical resources, as well as the lack of priority in implementing these programs. We believe that studies aimed at a deeper understanding of the reasons behind these difficulties could contribute to a clearer and more complete picture of the problem and enrich academic output on intersectoral partnerships.

\section{References}

Baptista, V. F. (2015). As políticas públicas de coleta seletiva no município do Rio de Janeiro: onde e como estão as cooperativas de catadores de materiais recicláveis? Revista de Administração Pública, 49(1), 141-164.

Bardin, L. (1977). Análise de conteúdo (Luis Antero Reto e Augusto Pinheiro, trad.). Lisboa: Edições, 70.

Besen, G. R., \& Ribeiro, H. (2006). Indicadores de sustentabilidade para programas municipais de coleta seletiva-métodos e técnicas de avaliação. In WORKSHOP INTERNACIONAL DE PESQUISA EM INDICADORES DE SUSTENTABILID ADE-WIPIS, II (pp. 159-174). 
Besen, G. R. (2011). Coleta seletiva com inclusão de catadores: construção participativa de indicadores e índices de sustentabilidade. São Paulo: Faculdade de Saúde Pública da USP.

Besen, G. I. N. A., Ribeiro, H., Rissogünther, W., \& Jacobi P. R. (2014). Coleta seletiva na região metropolitana de São Paulo: impactos da Política Nacional de Resíduos Sólidos. Ambiente \& Sociedade, 17(3).

Bhuiyan, S. H. (2010). A crisis in governance: Urban solid waste management in Bangladesh. Habitat International, 34(1), 125-133.

Buque, L. I. B., \& Ribeiro, H. (2015). Overview of the selective waste collection with pickers in Maputo municipality, Mozambique: challenges and perspectives. Saúde e Sociedade, 24(1), 298-307.

Bronzo, C., Teodósio, A. D. S. D. S., \& Rocha, M. C. G. D. (2012). Tri-sector partnerships in social entrepreneurship: discourse and practice of the actors from the circles of action and reflection. Revista de Administração (São Paulo), 47(3), 446-460.

Demajorovic, J., Besen, G. R., \& Rathsam, A. A. (2006). Os desafios da gestão compartilhada de resíduos sólidos face à lógica do mercado. Diálogos em ambiente e sociedade no Brasil.

Dias, S. L. F. G. (2009). Catadores: uma perspectiva de sua inserção no campo da indústria de reciclagem (Doctoral dissertation, Universidade de São Paulo).

Flick, U. (2009). Qualidade na pesquisa qualitativa: coleção pesquisa qualitativa. Bookman Editora.

Gil, A. C. (2008). Métodos e técnicas de pesquisa social. 6. ed. Ediitora Atlas SA.

Grafakos, S., BAUD, I., \& Klundert, A. (2001). Alliances in Urban Environmental Management. A process analysis for indicators and contributions to sustainable development in urban SWM. Working document, 14.

Grimberg, E., \& Blauth, P. (1998). Coleta seletiva: reciclando materiais, reciclando valores. In Coleta seletiva: reciclando materiais, reciclando valores. Pólis.

Hoornweg, D., \& Bhada-Tata, P. (2012). What a waste: a global review of solid waste management.

IBAM (Instituto Brasileiro de Administração Municipal). 2001. Manual: Gerenciamento Integrado de Resíduos Sólidos. Rio de Janeiro: IBAM/SEDU-PR.

IPEA - INSTITUTO DE PESQUISA ECONÔMICA APLICADA. Pesquisa sobre pagamento por servicos ambientais urbanos para gestão de resíduos sólidos. Brasília: Ipea, 2010. Disponível em: $\leq$ http://www.mma.gov.br/estruturas/253/arquivos/estudo do ipea 253.pdf>. Acesso em 25 de fevereiro de 2016.

Diagnóstico sobre os catadores de residuos sólidos. Brasília: IPEA, 2012. Disponível em: $\leq$ http://www.ipea.gov.br/agencia/images/stories/PDFs/relatoriopesquisa/121009 relatorio re s iduos_solidos_urbanos.pdf $>$. Acesso em 27 de fevereiro de 2016.

. Situação social dos catadores e catadoras de material reciclável e reutilizável - Brasil-Brasília: IPEA,

$2013 . \quad$ Disponível em:

<http://www.ipea.gov.br/agencia/images/stories/PDFs/situacao social/131219 relatorio situa

caosocial_mat_reciclavel_brasil.pdf $>$. Acesso em 10 de janeiro de 2016.

Kickbusch, I., \& Gleicher, D. (2012). Governance for health in the 21st century. Geneva: World Health Organization.

Loschiavo dos Santos, M. C. (2008). Consumo, descarte, catação e reciclagem: notas sobre design e multiculturalismo. Cadernos de Estudos Avançados em Design, v.1, Belo Horizonte: UEMG, Julho.

Ludke, M., \& André, A. (1986). Marli. Pesquisa em educação: abordagens qualitativas. São Paulo: EPU. 
McDonald, S. (2005). Studying actions in context: a qualitative shadowing method for organizational research. Qualitative research, 5(4), 455-473.

MNCR - MOVIMENTO NACIONAL DOS CATADORES DE MATERIAIS RECICLÁVEIS (2015). Princípios e objetivos do MNCR. Disponível em: $\leq$ http://www.mncr.org.br/sobre-Omncr/principios-e-objetivos >. Acesso em: 02 de abril de 2016.

. Artigos: A importância dos catadores já foi aceita, agora o debate é sobre a sua valorizaçãa, $05 \mathrm{de}$ dez. 2016. Entrevista. Disponível em: $\leq$ http://www.mncr.org.br/artigos/201ca-importancia-dos-catadores-ja-foiaceita-agora-o- debate-e-sobre-a-sua-valorizacao201d >. Acesso em: 05 de jan. 2017.

Najam, A. (2000). The four C's of government third Sector-Government relations. Nonprofit management and leadership, 10(4), 375-396.

Ocampo, J. A. (2018). Global economic and social governance and the United Nations system. Just Security in an Undergoverned World, 265.

PMU (2016). Relatório do Peso de materiais recicláveis destinados às associações e cooperativa. Relatório produzido pela Secretaria Municipal de Serviços Urbanos.

Quinlan, E. (2008). Conspicuous invisibility: Shadowing as a data collection strategy. Qualitative Inquiry, 14(8), 1480-1499.

SNIS - Sistema Nacional de Informações sobre Saneamento (2012). Sistema Nacional de Informaçoes sobre Saneamento: diagnóstico do manejo de resíduos sólidos urbanos - 2011. Brasília: MCIDADES.SNSA.

(2013). Sistema Nacional de Informações sobre Saneamento: diagnóstico do manejo de resíduos sólidos urbanos - 2012. Brasília: MCIDADES.SNSA.

(2014). Sistema Nacional de Informações sobre Saneamento: diagnóstico do manejo de resíduos sólidos urbanos - 2013. Brasília: MCIDADES.SNSA.

(2016). Sistema Nacional de Informações sobre Saneamento: diagnóstico do manejo de resíduos sólidos urbanos - 2014. Brasília: MCIDADES.SNSA.

(2017). Sistema Nacional de Informações sobre Saneamento: diagnóstico do manejo de resíduos sólidos urbanos - 2015. Brasília: MCIDADES.SNSA.

Teodósio, A., Gonçalves-Dias, S. F. L., Santos, M. C. L., \& Mswaka, W. (2015). From Outlaw to Regular Worker: trajectories, challenges and achievements of recyclers running social businesses in Brazil.

Veenstra, G. (2002). Social capital and health (plus wealth, income inequality and regional health governance). Social science \&o medicine, 54(6), 849-868.

Yin, R. K. (2015). Estudo de Caso-: Planejamento e Métodos. Bookman editora. 